\title{
PENENERAPAN PENDEKATAN RME UNTUK MENINGKATKAN HASIL BELAJAR MATEMATIKA SISWA KELAS VI SDIT RAUDHATURRAHMAH PEKANBARU
}

\author{
Fitria Anggraini ${ }^{1}$ \\ Universitas Pahlawan Tuanku Tambusaii ${ }^{1}$ \\ e-mail : fitriaanggraini@gmail.com
}

\begin{abstract}
Abstrak
Latar belakang masalah dalam penelitian ini adalah siswa mudah lupa dengan materi yang diajarkan dan kurang memahami konsep dengan baik karena kebermaknaan materi bagi anak kurang diperhatikan. Dalam pendekatan RME ini menekankan akan pentingnya konteks nyata yang dikenal siswa dan proses konstruksi pengetahuan matematika oleh siswa sendiri sehingga konsep yang diterima siswa lebih bermakna. Penelitian ini dalam bentuk Penelitian Tindakan Kelas (PTK) dengan subjek penelitian siswa kelas VI SDIT Raudhaturrahmah Pekanbaru tahun ajaran 2013/2014. Tujuan dalam penelitian ini adalah untuk meningkatkan hasil belajar matematika siswa kelas VI SDIT Raudhaturrahmah Pekanbaru pada materi Operasi Hitung Pecahan. Data dalam penelitian ini adalah data kuantitatif yang diperoleh dari tes pengetahuan dan pemahaman siswa melalui ulangan harian. Hasil penelitian ini menunjukkan bahwa rata-rata persentase aktivitas guru pada siklus I adalah 85,22\% (Kategori: Amat Baik) dan pada siklus II adalah 93,18\% (Kategori: Amat Baik). Sedangkan persentase aktivitas belajar siswa pada siklus I adalah 70,5\% (Kategori: Cukup) dan meningkat menjadi 86,3\% (Kategori: Baik) pada siklus II. Rata-rata hasil belajar siswa pada skor dasar adalah 69,2 meningkat menjadi 92,1 pada siklus I dan meningkat lagi menjadi 95,9 pada siklus II. Sedangkan ketuntasan klasikal pada siklus I dan siklus II tercapai. Ini artinya bahwa penerapan pendekatan pendidikan matematika realistik dapat meningkatkan hasil belajar matematika siswa kelas VI SDIT Raudhaturrahmah Pekanbaru.
\end{abstract}

Kata Kunci: RME, hasil belajar matematika

@Edukasi: Jurnal Ilmu Pendidikan FIP UPTT 2019

$\triangle$ Corresponding author:

Address : Pekanbaru

Email : fitriaanggraini@gmail.com

Phone : -
ISSN xxxx-xxxx (Media Cetak)

ISSN $x x x x-\operatorname{xxx}($ Media Online) 


\section{PENDAHULUAN}

\section{Matematika}

merupakan

ilmu

pengetahuan yang universal yang mendasari perkembangan teknologi modern, mempunyai peran penting dalam berbagai disiplin ilmu dan dapat melatih daya pikir manusia. Sesuai dengan fungsinya, pembelajaran matematika bertujuan untuk menghitung, mengukur, dan menggunakan rumus-rumus matematika yang diperlukan dalam kehidupan sehari-hari.

Tujuan pembelajaran matematika di Sekolah Dasar GBPP (Garis-garis Besar Program Pengajaran) secara umum adalah: 1) Mempersiapkan siswa agar mampu menghadapi perubahan yang ada di dalam kehidupan dan di dunia yang selalu berkembang melalui latihan atas dasar pemikiran secara logis, rasional, kritis, cermat, jujur, dan efektif. 2) Mempersiapkan siswa agar dapat menggunakan matematika dan pola pikir matematika dalam kehidupan sehari-hari dan dalam mempelajari berbagi ilmu pengetahuan. 3) Memecahkan masalah yang meliputi kemampuan memahami masalah, merancang model matematika, menyelesaikan model dan menafsirkan solusi yang diperoleh. 4) Mengkomunikasikan gagasan dengan simbol, tabel, diagram, atau media lain untuk memperjelas keadaan atau masalah. 5) Memiliki sikap menghargai kegunaan matematika dalam kehidupan, yaitu memiliki rasa ingin tahu, perhatian dan minat dalam mempelajari matematika, serta sikap ulet dan percaya diri dalam memcahkan masalah.

\section{Sementara tujuan pembelajaran} matematika di Sekolah Dasar (GBPP) secara khusus adalah: 1) Menumbuhkan dan mengembangkan keterampilan berhitung sebagai alat dalam kehidupan sehari-hari. 2) Menumbuhkan kemampuan siswa, yang dapat dialihgunakan melalui kegiatan matematika. 3) Mengembangkan kemapuan dasar matematika sebagai bekal belajar lebih lanjut di SLTP. 4) Membentuk sikap logis, kritis, kreatif, cermat dan disiplin.

Pada kenyataannya banyak kita dengar keluhan siswa tehadap matematika bahwa matematika cuma bikin pusing siswa (dan juga orang tuanya) bahkan dianggap sebagai hal yang menakutkan oleh sebagian siswa. Begitu beratnya peran dan tanggungjawab guru matematika yang membuat kekhawatiran siswa pada prestasi belajarnya. Faktor lain yang juga ikut mempengaruhi rasa bosan pada matematika adalah faktor penyampaian materi atau metode pembelajaran matematika yang monoton dan itu-itu saja. Hal ini jelas sangat berakibat buruk bagi perkembangan pendidikan matematika ke depan. Oleh karena itu, perubahan proses pembelajaran matematika yang menyenangkan harus menjadi prioritas utama. Hasil empiris di atas jelas merupakan suatu permasalahan yang merupakan faktor penting dalam mewujudkan tujuan pembelajaran matematika sesuai yang diamanatkan dalam kurikulum pendidikan matematika.

Berdasarkan pengamatan awal peneliti terhadap hasil belajar siswa kelas VI SDIT Raudhaturrahmah Pekanbaru pada mata pelajaran matematika yang peneliti ampu, selama tiga tahun berturut-turut dapat dilihat pada tabel 1 sebagai berikut:

Tabel 1.1

Persentase Hasil Belajar Matematika Siswa kelas VI SDIT Raudhatur Rahmah tahun 2010 - 2013

\begin{tabular}{|l|r|l|l|l|l|l|}
\hline No & $\begin{array}{r}\text { Ta } \\
\text { hun } \\
\text { Pelajaran }\end{array}$ & $\begin{array}{l}\text { Jumlah } \\
\text { Siswa }\end{array}$ & KM & $\begin{array}{l}\text { Tuntas } \\
\text { (anak) }\end{array}$ & $\begin{array}{l}\text { Tidak } \\
\text { Tuntas } \\
\text { (anak) }\end{array}$ & $\begin{array}{l}\% \\
\text { Ketunt } \\
\text { asan }\end{array}$ \\
\hline 1 & $\begin{array}{r}20 \\
10 / 2011\end{array}$ & 18 & 5 & 0 & & $44 \%$ \\
\hline 2 & $\begin{array}{r}20 \\
11 / 2012\end{array}$ & 21 & 7 & 0 & 1 & $52 \%$ \\
\hline 3 & $\begin{array}{r}20 \\
12 / 2013\end{array}$ & 23 & 7 & 5 & & $35 \%$ \\
\hline
\end{tabular}

Dari tabel di atas jelas terlihat bahwa hasil belajar matematika belum mencapai target yang seharusnya, dimana jika kurang dari $75 \%$ siswa tidak tuntas maka pembelajaran matematika dapat dikatakan belum berhasil.

Salah satu faktor penyebab rendahnya pemahaman siswa terhadap konsep-konsep matematika adalah pola pembelajaran yang dilaksanakan oleh guru. Pembelajaran matematika di Indonesia dewasa ini, "dunia 
11 Penerapan pendekatan RME untuk meningkatkan hasil belajar matematika siswa kelas VI SDIT Raudhaturrahmah Pekanbaru- Fitria Anggraini

nyata" hanya digunakan untuk mengaplikasikan konsep dan kurang mematematisasi "dunia nyata". Bila dalam pembelajaran di kelas, pengalaman anak sehari-hari dijadikan inspirasi penemuan dan pengkonstruksian konsep (pematematisasian pengalaman sehari-hari) dan mengaplikasikan kembali ke "dunia nyata" maka anak akan mengerti konsep dan dapat melihat manfaat matematika (I Gusti Putu Suharta, 2001).

Kebanyakan proses pembelajaran yang digunakan oleh guru adalah pembelajaran konvensional yakni ceramah, tanya jawab dan pemberian tugas. Dalam hal ini, proses pembelajaran didominasi oleh guru. Oleh karena itu, pendekatan pembelajaran tersebut perlu segera dirubah.

Berdasarkan permasalahan tersebut, mengingat bahwa untuk tahun pelajaran 2014/2015 masih dengan KKM yang sama yaitu 77 maka perlu dicari suatu pendekatan yang dapat mendukung proses pembelajaran matematika yang menyenangkan dan bukan menyeramkan sehingga dapat meningkatkan motivasi sekaligus mempermudah pemahaman siswa dalam belajar matematika dengan demikian hasil belajar siswa pun bisa meningkat (tercapai KKM). Salah satu pendekatan pembelajaran matematika saat ini yang dapat diterapkan adalah Rrealistic Mathematics Education (RME). RME ini sesuai dengan perubahan paradigma pembelajaran, yaitu dari paradigma mengajar ke paradigma belajar atau perubahan paradigma pembelajaran yang berpusat pada guru ke paradigma pembelajaran yang berpusat pada siswa. Hal ini adalah salah satu upaya dalam rangka memperbaiki mutu pendidikan matematika.

Melalui $R M E$ yang pengajarannya berangkat dari persoalan dalam dunia nyata, diharapkan pelajaran tersebut menjadi bermakna bagi siswa. Dengan demikian siswa termotivasi untuk terlibat dalam pelajaran. Untuk mendukung proses pembelajaran yang mengaktifkan siswa diperlukan suatu pengembangan materi pelajaran matematika yang difokuskan kepada aplikasi dalam kehidupan sehari-hari (kontekstual) dan disesuaikan dengan tingkat kognitif siswa, serta penggunaan metode evaluasi yang terintegrasi pada proses pembelajaran.

Dalam RME siswa didorong atau ditantang untuk aktif belajar, bahkan diharapkan dapat mengkonstruksi atau membangun sendiri pengetahuan yang diperolehnya (Dalyana, 2003:17). Berdasarkan pemikiran tersebut, maka penulis mencoba melakukan penelitian yang berjudul: "Penenerapan Pendekatan RME untuk Meningkatkan Hasil Belajar Matematika Siswa Kelas VI SDIT Raudhaturrahmah Pekanbaru.

\section{METODE PENELITIAN}

Bentuk penelitian ini adalah Penelitian Tindakan Kelas (PTK). Karena peneliti sekaligus guru yang mengajar di kelas yang peneliti teliti. Menurut Arikunto (2008) Penelitian Tindakan Kelas (PTK) dapat didefenisikan sebagai suatu bentuk penelitian yang bersifat reflektif dengan melakukan tindakan tertentu, agar dapat memperbaiki dan meningkatkan praktek pembelajaran di kelas secara profesional.

Menurut Kerlinger yang dikutip Yuli Sulistiyowati P.R (2005:55) desain penelitian adalah rencana dan struktur penyelidikan yang disusun sedemikian rupa sehingga peneliti akan dapat memperoleh jawaban untuk pertanyaan-pertanyaan penelitian.

Desain penelitian yang digunakan dalam penelitian ini adalah desain putaran spiral yang dikembangkan oleh Kemmis \& Mc Taggart (Kasihani Kasbolah, 1998:113). Dalam perencanaan Kemmis \& Mc Taggart menggunakan sistem spiral yang dimulai dengan perencanaan, tindakan, pengamatan, dan refleksi.

\section{HASIL PENELITIAN DAN PEMBAHASAN}

Berdasarkan analisis hasil penelitian, diperoleh kesimpulan dari aktivitas guru dan siswa serta ketercapaian KKM. Dari analisis data tentang aktivitas guru dan siswa telah sesuai dengan perencanaan. Semua siswa bisa bekerja secara aktif dan partisipasif dalam proses pembelajaran yang dilaksanakan. Melalui tahapan pembelajaran 
yang dilaksanakan, siswa dituntut untuk menyelesaikan permasalahan yang diberikan berdasarkan pengetahuan yang dimilikinya (konsep dunia nyata). Siswa dibimbing memahami pelajaran yang diberikan berdasarkan LKS dan bekerjasama dengan teman, meminta bimbingan dari guru, berani dan percaya diri untuk mempresentasikan hasil kerja serta menanggapi hasil presentasi temannya. Siswa juga berusaha untuk menyelesaikan soal yang diberikan guru. Proses pembelajaran dengan pendekatan pendidikan matematika realistik menjadikan siswa tertarik dan aktif didalam proses pembelajaran.

Berdasarkan pengamatan peneliti, pada awal pertemuan siswa masih bingung dalam mengikuti pendekatan pembelajaran yang digunakan peneliti. Hal ini disebabkan penggunaaan pendekatan pembelajaran matematika realistik ini merupakan pengalaman pertama bagi siswa. Namun pada pertemuan selanjutnya siswa sudah mulai memahami dan bisa mengikuti pendekatan pembelajaran yang diterapkan. Dalam mengikuti setiap aktivitas pembelajaran siswa berusaha memahmi materi ajar yang diberikan dan mengerjakan LKS dengan diskusi bersama teman sebangku serta bertanya dengan guru jika ada langkah-langkah kegiatan yang tidak dimengerti.

Berdasarkan hasil belajar ulangan siklus I, dapat disimpulkan ketercapaian kompetensi berdasarkan indikator sudah mencapai KKM secara keseluruhan.. Hanya beberapa orang saja yang kesulitan mengerjakan soal pada indikator 2 yaitu menyederhanakan pecahan. Berdasarkan pengamatan peneliti, hal ini dikarenakan siswa yang kurang teliti dan cermat dalam menjawab soal pada indikator tersebut. Indikator 1 dan 2 ketuntasan mencapai $93 \%$ dan indikator 2 adalah $79 \%$. Sehingga persentase ketuntasan KKM pada siklus I adalah $86,2 \%$ dan secara klasikal tuntas.hal ini dapat dilihat pada lampiran $\mathrm{J} 1$ dan $\mathrm{J} 2$

Berdasarkan hasil belajar siswa pada siklus II, pada indikator 1 yaitu mengubah bentuk pecahan biasa menjadi pecahan desimal dan persen seluruh siswa sudah mencapai ketuntasan indikator, yaitu $100 \%$. Begitu juga pada indikator 2 yaitu siswa dapat mengubah bentuk pcahan desimal atau persen ke pecahan biasa sudah mencapai ketuntasan indikator 100\%. Secara umum siswa tidak ada masalah dalam mengerjakan ulangan pada indikator 1 dan 2 . Pada umumnya mereka telah memahami bagaimana mengubah bentuk suatu pecahan ke bentuk lainnya dan sebaliknya. Sehingga persentase persentase ketuntasan KKM pada siklus II yaitu $100 \%$ dan secara klasikal siklus II tuntas.

Berdasarkan nilai rata-rata siswa juga terjadi peningkatan dari Skor Dasar, Siklus I, dan Siklus II. Rata-rata siswa pada skor dasar adalah 69,2, meningkat sebesar 22,9 dengan persentase peningkatan $33,09 \%$ pada siklus I menjadi 92,1 dan meningkat lagi sebesar 3,8 dengan persentase 4,1\% menjadi 95,9

Dari analisis data tentang ketercapaian tujuan penelitian, diperoleh fakta bahwa terjadi peningkatan skor hasil belajar siswa sesudah tindakan dibandingkan dengan skor hasil belajar siswa sebelum tindakan. Dari pembahasan di atas disampaikan bahwa hipotesis tindakan yang diajukan dapat diterima. Dengan kata lain penerapan pendekatan pendidikan matematika realistik dapat meningkatkan hasil belajar matematika siswa kelas VI SDIT Raudhaturrahmah Pekanbaru khususnya pada materi pokok Operasi Hitung Pecahan tahun pelajaran 2013/2014.

Dari penelitian ini juga menunjukkan kebenaran kajian teori pendekatan pendidikan matematika realistik dapat menjadi alternatif pembelajaran yang dapat meningkatkan hasil belajar siswa. Pendidikan matematika realistik adalah suatu pendekatan yang menghubungkan proses pembelajaran dengan dunia nyata anak (lingkungan) sehingga siswa mudah memahami konsep pelajaran yang diberikan.

\section{KESIMPULAN}

Berdasarkan hasil penelitian dan pembahasan yang dilakukan dapat disimpulkan bahwa pendekatan RME dapat meningkatkan hasil belajar matematika siswa kelas VI SDIT Raudhaturrahmah Pekanbaru yang dibuktikan dengan:

1. Rata- rata persentase aktivitas guru selama melaksanakan kegiatan pembelajaran meningkat dari $85,22 \%$ (Kategori: Amat Baik) pada siklus I menjadi 93,18\% (Kategori: Amat Baik) pada siklus II.

2. Rata-rata persentase aktivitas belajar siswa dalam kegiatan pembelajaran 
13 Penerapan pendekatan RME untuk meningkatkan hasil belajar matematika siswa kelas VI SDIT Raudhaturrahmah Pekanbaru- Fitria Anggraini

yang dilaksanakan mengalami peningkatan dari 70,5\% (Kategori: Cukup) pada siklus I, menjadi $86,3 \%$ (Kategori: Amat Baik) pada siklus II.

3. Jumlah siswa yang mencapai KKM sebelum tindakan (skor dasar) adalah 17 orang $(58,62 \%)$. Terjadi peningkatan pada siklus I, siswa yang tuntas menjadi 21 orang $(86,49 \%)$. Sedangkan pada siklus II siswa yang tuntas 29 orang (100\%).

4. Hasil belajar siswa secara klasikal pada Skor Dasar adalah 69,2, pada Siklus I meningkat sebesar 22,9 dengan persentase peningkatan 33,09\% menjadi 92,1. Pada Siklus II dan meningkat lagi sebesar 3,8 dengan persentase $4,1 \%$ menjadi 95,9

Berdasarkan kesimpulan dan pembahasan hasil penelitian dengan penerapan pendekatan pendidikan matematika realistik yang telah dilaksanakan, peneliti mengajukan beberapa saran:

1. Bagi guru dan sekolah, pendekatan pendidikan matematika realistik dapat dijadikan salah satu alternatif dalam pembelajaran matematika guna meningkatkan hasil belajar siswa.

2. Harus ada tindak lanjut bagi guru terhadap siswa yang tidak tuntas pada ulangan siklus (UH I dan UH II) dengan cara memberikan bimbingan/remedial agar siswa tersebut mencapai KKM yang ditetapkan.

Bagi peneliti lanjutan, dalam proses pembelajaran agar dapat mengatur waktu dengan sebaik-baiknya terutama ketika siswa mengerjakan LKS yang diberikan. Sehingga proses pembelajaran dengan menggunakan pendekatan pendidikan matematika realistik dapat berjalan dengan baik

\section{DAFTAR PUSTAKA}

Aisyah, Nyimas, dkk. 2007. Pengembangan Pembelajaran Matematika SD. Jakarta : Direktorat Jenderal Pendidikan Tinggi Departemen Pendidikan Nasional

Arikunto, Suharsimi. 2010. Dasar-Dasar Evaluasi Pendidikan.Jakarta: Bumi Aksara

Arikunto, Suharsimi. 2005. Manajemen Penelitian. Jakarta: Rineka Cipta.

Arikunto,Suharsimi, dkk Tt. 2006. Penelitian Pendidikan Kelas. Jakarta : Bumi Aksara.

Djamarah, Syaiful Bahri. 2008. Psikologi Pendidikan. Jakarta : PT. Rineka Cipta.

Daryanto. 2010. Evaluasi Pendidikan. Jakarta : Rineka Cipta.

Gravemeijer, K. 1994. Developing Realistic Mathematics Education. Trech : CD Press.

Hamalik. 2003. Proses Belajar Mengajar. Jakarta : PT. Bumi Aksara.

Purwanto, M. Ngalim. 2007. Prinsip-Prinsip dan Teknik Evaluasi Pengajaran. Bandung : PT. Remaja Rosdakarya.

Ruseffendi, ET. 1988. Pengantar Kepada Membantu Guru Mengembangkan Kompetensinya dalam Pengajaran Matematika untuk Meningkatkan CBSA Bandung: Tarsito..

Sudjana, Nana. 2003. Penilaian Hasil Proses Belajar Mengajar. Bandung : $\mathrm{R}$ Rosdakarya

Syahrifuddin,dkk. 2009. Psikologi Pendidikan. Pekanbaru: Cendikia Insani 
14 Penerapan pendekatan RME untuk meningkatkan hasil belajar matematika siswa kelas VI SDIT Raudhaturrahmah Pekanbaru- Fitria Anggraini

Syahrifuddin,dkk. 2011. Bahan Ajar Penelitian Tindakan Kelas. Pekanbaru: Cendikia Insani

Slameto. 2010. Belajar dan Faktor-Faktor Mempengaruhinya. Jakarta : Renika Cipta.

Sulistyowati, Sofchah. 2001. Cara Belajar Yang Efektif dan Efisien. Pekalongan : Cinta Ilmu Pekalongan

Sutikno, Sobry, M.. 2007. Menggagas Pembelajaran Efektif dan Bermakna. Mataram : NTP Press

Sudjana, Nana. 2005. Penilaian Hasil Proses Belajar Mengajar, Bandung: PT. Remaja Rosdikarya.

Sudjana, Nana. 2002. Penilaian Hasil Proses Belajar Mengajar. Bandung: Remaja Rosdakarya.

Uno, H. 2011. Model-Model Pembelajaran. Jakarta : Bumi Aksara. 